
November 1934

\title{
RESISTIVITY OF SULPHURIC-ACID SOLUTIONS AND ITS RELATION TO VISCOSITY AND TEMPERATURE
}

\author{
By George W. Vinal and D. Norman Craig
}

ABSTRACT

The resistivity of sulphuric-acid solutions ranging from 15 to 45 percent acid has been measured at temperatures of +30 to $-40^{\circ} \mathrm{C}$, except as the measurements of some solutions were limited by their freezing points. The resistivity of these solutions at $0^{\circ} \mathrm{C}$ is about 1.7 times that at $+30^{\circ} \mathrm{C}$, but at $-40^{\circ} \mathrm{C}$ the resistivity is 5.5 times as great. The composition of solutions having minimum resistivity (maximum conductivity) was found to depend on the temperature. At $18{ }^{\circ} \mathrm{C}$ the solution having minimum resistivity was found to be 30.4 percent, as previously determined by Kohlrausch, but at $-25^{\circ} \mathrm{C}$ the solution of minimum resistivity contains only 26.5 percent acid. Values of resistivity for each interval of 5 percent in composition and $5^{\circ} \mathrm{C}$ in temperature are given. An empirical relation between resistivity, kinematic viscosity, and absolute temperature was found to hold for concentrated solutions over a temperature range from +30 to $-40^{\circ} \mathrm{C}$.

CONTENTS

I. Introduction

II. The apparatus... 690

III. Experimental results

IV. Solutions having minimum resistivity

V. Relation between resistivity, kinematic viscosity, and temperature .- 695

VI. Comparison with previous determinations...

VII. Accuracy of the measurements .

\section{INTRODUCTION}

In a paper ${ }^{1}$ on the viscosity of sulphuric-acid solutions it was stated that both resistivity and viscosity of battery electrolytes are important factors in determining the amount of electrical energy which can be delivered by a battery under specified conditions of temperature and rate of discharge. Storage batteries are now used under such widely differing temperature conditions that an extension of our knowledge of the basic properties of sulphuric-acid solutions became necessary. In the viscosity paper, measurements on solutions ranging in concentration from 10 to 50 percent $\mathrm{H}_{2} \mathrm{SO}_{4}$ were reported for temperatures between +30 and $-50^{\circ} \mathrm{C}$. The present paper reports resistivities of similar solutions between +30 and $-40^{\circ} \mathrm{C}$, insofar as the temperatures are above the freezing points of the solutions.

1 Vinal and Craig, BS J.Research 10,781(1933);RP566. We shall have occasion to refer to this paper frequently and it will be called the "viscosity paper", without further specific reference. 
We have chosen to express the results as resistivities rather than as conductivities, because the resistivity of the solutions is more conveniently used in engineering problems. Corresponding conductivities can be calculated readily by taking reciprocals of the values for resistivity.

Data previously available for conductivity and resistivity of sulphuric-acid solutions have served as a basis for values reported in the International Critical Tables, ${ }^{2}$ but no data for the resistivity of sulphuric-acid solutions below $0^{\circ} \mathrm{C}$ have been found. In a later section of the present paper comparison is made between our determinations and the data which are given in the International Critical Tables. Such a comparison is limited, however, to few values, since our work covered relatively concentrated solutions at low temperatures, while previous work was confined for the most part to measurements of dilute solutions at higher temperatures.

Much of the apparatus for controlling and measuring the temperature of the condutivity cells was the same as that described in the viscosity paper. For many details of the present work, reference is made to that paper, the results of the resistivity measurements being presented as briefly as possible.

\section{THE APPARATUS}

Two conductivity cells, similar in design to the Washburn type C cells, were employed. The electrodes in these cells were platinized platinum, about $1.5 \mathrm{~cm}$ in diameter. The small size of electrodes in our cells was made possible by the use of a two-stage amplifier in the detector circuit. This arrangement afforded ample sensitivity, although the current through the cells was very small. The heating effect of the test current was negligible.

We employed a Parker solution ${ }^{3}$ of $76.627_{6} \mathrm{~g}$ of purified potassium chloride per kilogram of distilled water to determine the constants of the cells. Five determinations at $25^{\circ} \mathrm{C}$ were made on each cell and a correction of $0.01 \mathrm{ohm}$ was made for the leads. This correction was calculated and subsequently verified by filling the cells with mercury. The mean values of the constants were found to be:

Cell no. 1 73. 378

Cell no. 2

Since the constant for cell no. 1 is more than four times that of cell no. 2 measurements were made to show that these cells gave concordant results when measuring a particular solution of sulphuric acid over a wide range of temperatures. The ratio of the observed resistance with the two cells is given in table 1 . The agreement of results obtained is within 0.1 percent on the average.

2 International Critical Tables 6,241(1929).
3 International Critical Tables 6,230(1929). 
TABLE 1.-Comparison of measurements with cells, nos. 1 and 2

\begin{tabular}{|c|c|c|c|c|}
\hline Temperature & Solution & $\begin{array}{l}\text { Ratio of } \\
\text { resistance- } \\
\text { cell 1:cell 2 }\end{array}$ & $\begin{array}{l}\text { Difference } \\
\text { from KCl } \\
\text { ratio }\end{array}$ & Differences \\
\hline${ }^{\circ} \mathrm{C}$ & \multirow{12}{*}{ 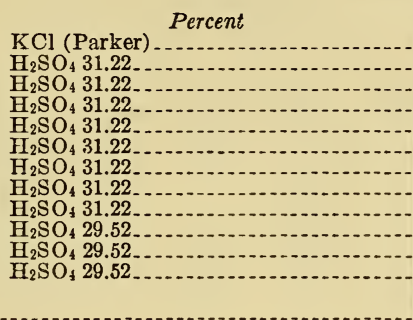 } & \multirow{11}{*}{$\begin{array}{l}4.158 \\
4.153 \\
4.158 \\
4.156 \\
4.155 \\
4.151 \\
4.156 \\
4.166 \\
4.163 \\
4.159 \\
4.157 \\
4.158\end{array}$} & & Percent \\
\hline 30-- & & & 0.005 & -0.12 \\
\hline 25 & & & .000 & 0.00 \\
\hline $20 \ldots$ & & & .002 & -0.05 \\
\hline 18 & & & .003 & -0.07 \\
\hline 15 & & & .007 & -0.17 \\
\hline $10 \ldots$ & & & .002 & -0.05 \\
\hline & & & .008 & +0.19 \\
\hline & & & $\begin{array}{l}.005 \\
.001\end{array}$ & $\begin{array}{l}+0.12 \\
+0.02\end{array}$ \\
\hline & & & .001 & -0.02 \\
\hline & & & .000 & 0.00 \\
\hline Average & & & & \pm 0.07 \\
\hline
\end{tabular}

The change with temperature in the constant for type $\mathrm{C}$ cells has been calculated to be less than 0.02 percent at $0^{\circ} \mathrm{C}$ on the basis of data given by Washburn. ${ }^{4}$ At $-40^{\circ} \mathrm{C}$ this error should not amount to more than 0.05 percent. No corrections for change in cell constant have been necessary in calculating our results.

The bridge which was employed in making the measurements was designed particularly for measuring the resistance of storage-battery separators and will be described in detail in a forthcoming publication on that subject. Briefly, it consisted of two equal ratio arms having resistances of $10 \mathrm{ohms}$. Precision resistance coils were used in these arms. The third arm of the bridge included a decade resistance box having $0.1-\mathrm{ohm}$ steps in the last dial. The fourth arm included the conductivity cell. Between the resistance box and the cell was a slide wire about $50 \mathrm{~cm}$ long having a resistance of slightly more than 0.05 $\mathrm{ohm}$. The test current for the bridge was supplied by a 1,000-cycle oscillator and the detector circuit included a two-stage audio amplifier.

The bridge was balanced approximately by moving a contact of the detector circuit along the slide wire. Then the adjustment of a small mutual inductance, which coupled the telephone detector circuit to the bridge circuit, permitted balancing any out-of-phase component of potential difference in the bridge. Following this, the contact to the slide wire was again moved until the final balance of the bridge was obtained. For this very satisfactory device for balancing the bridge the authors are indebted to Dr. F. Vienner of this Bureau. Details of it have been published by him. ${ }^{5}$ Settings of the bridge could be made and repeated to within 0.1 percent.

The temperature control for the conductivity cells was similar to that described in the viscosity paper. It is unnecessary to describe it further. No attempt was made to carry the resistivity measurements to as low temperatures as those in the viscosity work because the mercury contacts of the cells would have frozen.

J. Am. Chem. Soc. 38, 2455(1916).

S BS J. Research 5,714(1930); R P223. 


\section{EXPERIMENTAL RESULTS}

The composition of each solution was determined by titrating 2 weighed portions.

The concentration of acid was then expressed as the percentage of $\mathrm{H}_{2} \mathrm{SO}_{4}$. The percentages so obtained were $14.68,21.41,28.13,29.52$, $30.43,31.22,33.89,40.17$, and 45.45 . As a check on these determinations, the specific gravity of each solution was measured with calibrated hydrometers which could be read to 0.0005 . From these measurements the percentage of $\mathrm{H}_{2} \mathrm{SO}_{4}$ was calculated by using data in the International Critical Tables. The average difference between the results of the titrations and the specific-gravity measurements was less than 0.1 percent of sulphuric acid, excepting the one case of 45.45 percent acid for which the difference amounted to 0.2 percent. The results given in this paper are based entirely on the values determined by titration.

Some of these solutions are the same as those used for the viscosity determinations, but we have added three solutions in the middle range, since the percent composition of solutions having minimum resistivity changes with temperature.

Experimental curves showing the relation between the measured resistance of the cell ( 85 to $650 \mathrm{ohms}$ for cell no. 1 and 25 to $90 \mathrm{ohms}$ for cell no. 2) and the temperature were plotted on a large scale, but the curvature made it difficult to interpolate values with the accuracy which we desired. We resorted, therefore, to a plot similar to that of figure 3 of the viscosity paper. After several trials it was found that plotting the function $\frac{1}{\log (6 \times \text { resistivity })}$ against the temperature yielded a nearly linear relation throughout the range of temperature from +30 to $-40^{\circ} \mathrm{C}$. Interpolation and, in a few cases, extrapolation over a few degrees could be accomplished easily and accurately. Individual points which were plotted were in some cases the mean result of as many as 6 or 8 determinations. After reading from the curves the values of $\frac{1}{\log (6 \times \text { resistivity })}$ for each 5 -degree interval, isothermal curves were plotted for the logarithmic function against percentage composition of the acid. These curves, however, could not be used as advantageously for determining resistivities at even percentages of the acid as when the resistivities, calculated from the values of the function were plotted. The curves of the logarithmic function against percent composition had one great advantage, however, in determining the points of minimum resistivity since the curvature is accentuated in this region.

We have used both sets of curves, that is, resistivity against percent composition and the logarithmic function against percent composition, in determining the values for resistivity of sulphuric-acid solutions given in table 2. One set of curves has been used as a check on the other. In no case was any large discrepancy noted between the results from the two curves, but we have given the greater weight to determinations based on the plot of resistivity against percent composition, because the curvature of these is less than for the others.

Table 2 gives the complete results of our measurements. In rounding off values, we have followed the same rule as in the viscosity determinations, that is, four significant figures are given for values 
less than 2.500 which are at or above $0^{\circ} \mathrm{C}$. Three figures are given for the remainder.

TABLE 2.-Resistivity of sulphuric-acid solutions

\begin{tabular}{|c|c|c|c|c|c|c|c|}
\hline Temperature & 15 percent & 20 percent & 25 percent & 30 percent & 35 percent & 40 percent & 5 perce \\
\hline $\begin{array}{l}{ }^{\circ} \mathrm{C} \\
{ }^{6}\end{array}$ & \begin{tabular}{c}
$o h m-c m$ \\
1.596 \\
1.689 \\
1.800 \\
1.852 \\
1.932 \\
2.090 \\
2.279 \\
2.51 \\
2.79 \\
\hdashline
\end{tabular} & $\begin{array}{c}\text { ohm-cm } \\
1.313 \\
1.396 \\
1.494 \\
1.541 \\
1.613 \\
1.755 \\
1.922 \\
2.128 \\
2.38 \\
2.69\end{array}$ & $\begin{array}{r}\text { ohm-cm } \\
1.180 \\
1.261 \\
1.357 \\
1.401 \\
1.470 \\
1.606 \\
1.768 \\
1.961 \\
2.20 \\
2.50 \\
2.87 \\
3.35\end{array}$ & $\begin{array}{c}\text { ohm-cm } \\
1.131 \\
1.214 \\
1.311 \\
1.355 \\
1.426 \\
1.563 \\
1.727 \\
1.930 \\
2.18 \\
2.49 \\
2.88 \\
3.39 \\
4.09 \\
5.00 \\
6.20\end{array}$ & \begin{tabular}{r|} 
ohm-cm \\
1.140 \\
1.231 \\
1.334 \\
1.380 \\
1.454 \\
1.602 \\
1.782 \\
1.998 \\
2.27 \\
2.60 \\
3.01 \\
3.57 \\
4.32 \\
5.29 \\
6.59 \\
8.39
\end{tabular} & $\begin{aligned} \text { ohm-cm } \\
1.203 \\
1.301 \\
1.415 \\
1.467 \\
1.549 \\
1.710 \\
1.906 \\
2.146 \\
2.44 \\
2.81 \\
3.27 \\
3.86 \\
4.65 \\
5.73 \\
7.18 \\
9.09\end{aligned}$ & $\begin{array}{l}\text { ohm-cm } \\
\text { 1. } 312 \\
1.422 \\
1.549 \\
1.608 \\
1.702 \\
1.885 \\
2.104 \\
2.371 \\
2.70 \\
3.10 \\
3.63 \\
4.31 \\
5.21 \\
6.35 \\
7.90 \\
9.89\end{array}$ \\
\hline
\end{tabular}

Figure 1 shows the results graphically and also the relation of resistivity to the specific gravity of the solutions.

\section{SOLUTIONS HAVING MINIMUM RESISTIVITY}

It has long been known that solutions of about 30 percent sulphuric acid have minimum resistivity. The Kohlrausch solution having minimum resistivity at $18^{\circ} \mathrm{C}$ was specified by him ${ }^{6}$ as 30 percent $\mathrm{H}_{2} \mathrm{SO}_{4}$, having a density of 1.223 at $18^{\circ} \mathrm{C}$. The specified percentage is not entirely consistent with the density. His table on page 157 shows that a density of 1.223 at $18^{\circ} \mathrm{C}$ corresponds to 30.3 percent $\mathrm{H}_{2} \mathrm{SO}_{4}$ and later tables ${ }^{7}$ indicate that 30.4 percent ( 30.36 percent) is more nearly correct. Our table 3 shows that we also have found the solution, which has the maximum conductivity at $18^{\circ} \mathrm{C}$, to contain 30.4 percent acid.

The conductivity of the solution which has the maximum conductivity at $25^{\circ} \mathrm{C}$ is given in table 3 as 0.8243 reciprocal ohm-centimeters. This is in close agreement with the value given in the International Critical Tables ${ }^{8} 0.8242$, which is based on the work of Eastman. ${ }^{9}$ It is not entirely certain, however, that the percentage composition of his solution was precisely the same as ours. A variation of a few tenths of a percent in composition of the solution makes an exceedingly small change in conductivity in the region of maximum conductivity. It is probable that the difference between Eastman's result at $25^{\circ} \mathrm{C}$ and ours is not less than 1 nor more than 4 parts in 8,200.

\footnotetext{
6 Kohlrausch und Holborn, Das Leitvermögen der Elektrolyte 75 (1916).

7 International Critical Tables 3,56(1928).

8 International Critical Tables 6,230(1929).

$\checkmark$ J. Am. Chem. Soc. 46,333(1924).
} 


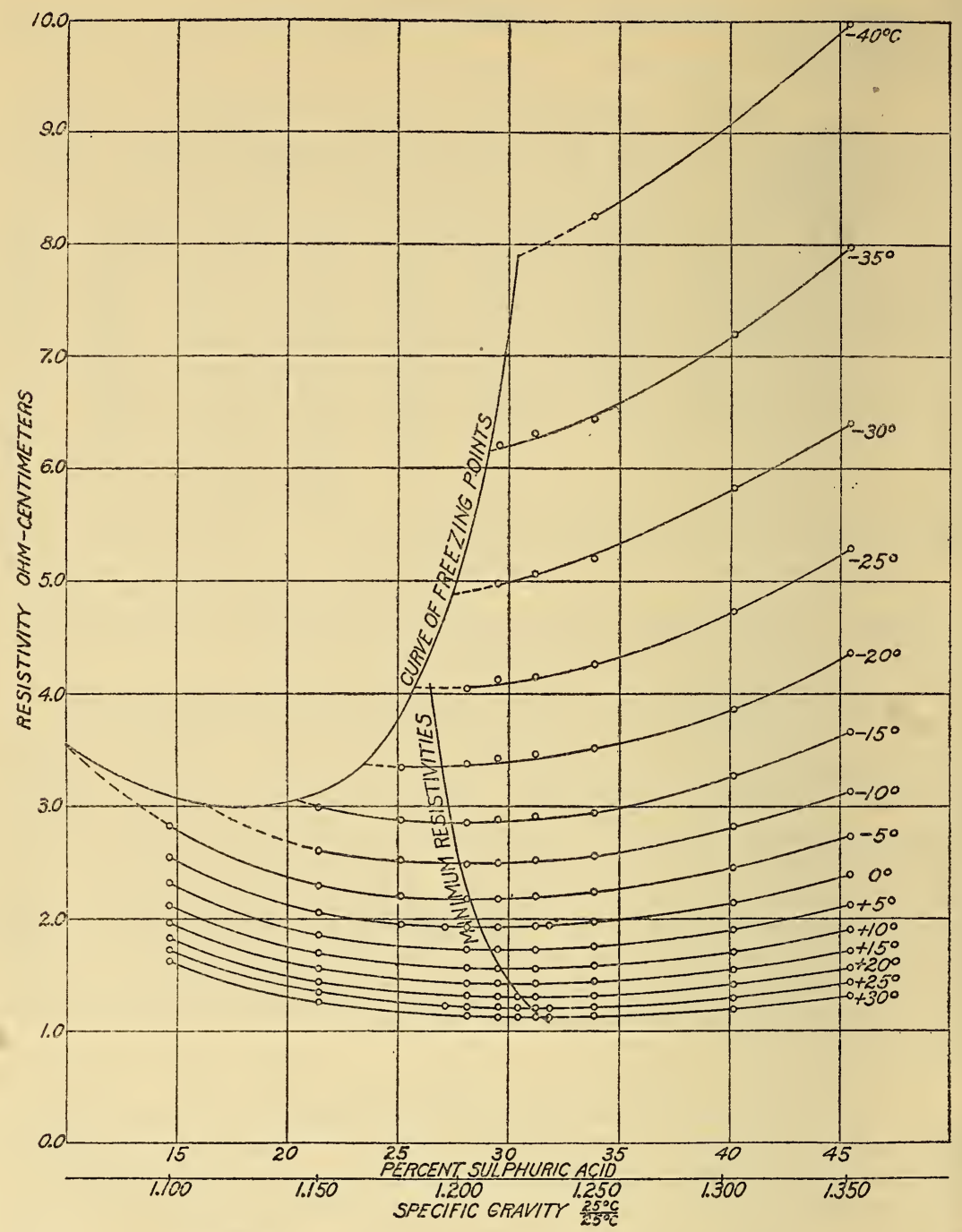

FIGURE 1.-Resistivity of sulphuric-acid solutions.

TABLE 3.-Concentration of solutions having minimum resistivity at various temperatures

\begin{tabular}{|c|c|c|c|c|c|c|c|}
\hline Temperature & $\begin{array}{l}\text { Concen- } \\
\text { tration }\end{array}$ & $\underset{\text { ity }}{\text { Resistiv- }}$ & $\begin{array}{l}\text { Conduc- } \\
\text { tivity }\end{array}$ & Temperature & $\begin{array}{l}\text { Concen- } \\
\text { tration }\end{array}$ & $\underset{\text { ity }}{\text { Resistiv- }}$ & Conduc- \\
\hline $\begin{array}{c}{ }^{\circ} \mathrm{C} \\
+30 \\
25 \\
20 \\
18 \\
15 \\
10\end{array}$ & $\begin{array}{r}\text { Percent } \\
31.5 \\
31.1 \\
30.6 \\
30.4 \\
30.2 \\
29.8 \\
29.3\end{array}$ & $\begin{array}{c}\text { ohm-cm } \\
1.129 \\
1.2132 \\
1.310 \\
1.353 \\
1.425 \\
1.562 \\
1.726\end{array}$ & $\begin{array}{r}\text { 1/ohm-cm } \\
0.8855 \\
0.8243 \\
0.7635 \\
0.7388 \\
0.7015 \\
0.6402 \\
0.5794\end{array}$ & $\begin{array}{c}{ }^{\circ} \mathrm{C} \\
0 \\
-5 \\
-10 \\
-15 \\
-20 \\
-25\end{array}$ & $\begin{array}{r}\text { Percent } \\
28.8 \\
28.4 \\
27.9 \\
27.4 \\
26.9 \\
26.5\end{array}$ & $\begin{array}{c}\text { ohm-cm } \\
1.928 \\
2.17 \\
2.48 \\
2.86 \\
3.34 \\
\vdots 4.05\end{array}$ & $\begin{array}{c}1 / \text { ohm-cm } \\
0.5187 \\
0.461 \\
0.403 \\
0.350 \\
0.299 \\
0.247\end{array}$ \\
\hline
\end{tabular}


Our results show clearly that the composition of the solution having minimum resistivity (maximum conductivity) is not the same for all temperatures. As the temperature is lowered, the percentage of $\mathrm{H}_{2} \mathrm{SO}_{4}$ must be decreased slightly to obtain minimum resistivity. Thus, at $+30^{\circ} \mathrm{C}$ we find the solution having least resistivity to contain 31.5 percent $\mathrm{H}_{2} \mathrm{SO}_{4}$ and at $-25^{\circ} \mathrm{C}$ the solution to contain 26.5 percent acid.

Table 3 gives the percentage composition of solutions having minimum resistivity for each $5^{\circ} \mathrm{C}$ interval between +30 and $-25^{\circ} \mathrm{C}$. In this table we have included also the conductivities of the respective solutions for comparison with existing data.

\section{RELATION BETWEEN RESISTIVITY, KINEMATIC VISCOSITY, AND TEMPERATURE}

In the third section of this paper it was stated that an approximately linear relation between a function of resistivity of the sulphuric-acid solutions and temperature was obtained by plotting the function

\section{$\frac{1}{\log (6 \times \text { resistivity })}$}

against the temperature. This function, which we shall call "function $A$ " for convenience, was obtained empirically. The relation between function $A$ and the temperature was more nearly linear in the case of the higher concentrations than for the lower concentrations (21.4 and 14.7 percent $\mathrm{H}_{2} \mathrm{SO}_{4}$ ). The slight curvature of the plotted lines for these caused no inconvenience in interpolating values, but may have been of some significance in the computations which follow, particularly as the curvature was most pronounced at the higher temperatures. The unit of resistivity which we employ in the following discussion is the ohm-centimeter as in table 2 .

A similar linear relationship was shown to exist between temperature and the function

$$
\frac{1}{\log (20 \times \text { kinematic viscosity })}
$$

The plot of this was shown in figure 3 of the viscosity paper. We shall call this function of viscosity "function $B$." The unit of kinematic viscosity employed here is the same as that which we used in the viscosity paper, namely, the centistoke.

The existence of these two linear relationships suggested the possibility of finding a simple relation between resistivity, kinematic viscosity, and temperature. By purely empirical methods, we have found that the ratio of function $A$ to function $B$ divided by the square root of the absolute temperature, $T$, gives a constant for solutions ranging from 28 to 45 percent $\mathrm{H}_{2} \mathrm{SO}_{4}$ over the wide range of temperature from +30 to $-40^{\circ} \mathrm{C}$. The relation is less exact for the lower concentrations, 21.4 and 14.7 percent $\mathrm{H}_{2} \mathrm{SO}_{4}$. The reason for this may be the greater departure from a linear relation between function $A$ and temperature or may involve the constitution of the solutions, since these 
particular solutions are on the dilute side of the region of minimum resistivity. The relation is expressed as follows:

or

$$
\begin{aligned}
& \frac{\text { Function } A}{\sqrt{T} \text { Function } B}=\text { constant } \\
& \frac{\text { Function } A}{\text { Function } B}=\text { constant } \sqrt{T}
\end{aligned}
$$

Table 4 gives the complete data for calculating the ratio of function $A$ to function $B$. The table shows that this ratio is proportional to the square root of the absolute temperature, at least for solutions of $45.5,40.2,33.9$, and 28.1 percent $\mathrm{H}_{2} \mathrm{SO}_{4}$. In the last column of the table we have given the computed value of the constant of equation 1. The average deviation of a single value from the mean value of this constant is 1 percent for the more concentrated solutions and 5 percent if all the determinations are included. It is perhaps significant in the case of the more dilute solutions that the value of the constant approached more nearly to the average value for all when these solutions were at the lowest temperatures. It was in the region of lowest temperatures that the relation between function $A$ and temperature was more nearly linear for these two solutions.

\begin{tabular}{|c|c|c|c|c|c|c|c|}
\hline Concentration & Temp & ature & $\begin{array}{c}\text { Function } \\
\qquad A\end{array}$ & $\underset{B}{\text { Function }}$ & $A / B$ & $\sqrt{T}$ & $\frac{A}{B \sqrt{\bar{T}}}$ \\
\hline $45.5 \ldots$ & $\left\{\begin{array}{r}\circ C \\
30 \\
15 \\
0 \\
-15 \\
-30 \\
-40\end{array}\right.$ & $\begin{array}{r}A b s . \\
303 \\
288 \\
273 \\
258 \\
243 \\
233\end{array}$ & $\begin{array}{r}1.1110 \\
.9868 \\
.8641 \\
.7444 \\
.6299 \\
.5654\end{array}$ & $\begin{array}{r}0.6312 \\
.5791 \\
.5245 \\
.4692 \\
.4116 \\
.3727\end{array}$ & $\begin{array}{l}1.76 \\
1.70 \\
1.65 \\
1.59 \\
1.53 \\
1.52\end{array}$ & $\begin{array}{l}17.4 \\
17.0 \\
16.5 \\
16.1 \\
15.6 \\
15.3\end{array}$ & $\begin{array}{r}0.101 \\
.100 \\
.100 \\
.099 \\
.098 \\
.099\end{array}$ \\
\hline $40.2 \ldots$ & $\begin{array}{r}30 \\
15 \\
0 \\
-15 \\
-30 \\
-40\end{array}$ & $\begin{array}{l}303 \\
288 \\
273 \\
258 \\
243 \\
233\end{array}$ & $\begin{array}{r}1.1644 \\
1.0316 \\
.9000 \\
.7722 \\
.6504 \\
.5706\end{array}$ & $\begin{array}{l}.6558 \\
.5985 \\
.5396 \\
.4802 \\
.4204 \\
.3802\end{array}$ & $\begin{array}{l}1.77 \\
1.73 \\
1.67 \\
1.61 \\
1.55 \\
1.50\end{array}$ & $\begin{array}{l}17.4 \\
17.0 \\
16.5 \\
16.1 \\
15.6 \\
15.3\end{array}$ & $\begin{array}{l}.102 \\
.102 \\
.101 \\
.100 \\
.099 \\
.098\end{array}$ \\
\hline 33.9 & $\begin{array}{r}30 \\
15 \\
0 \\
-15 \\
-30 \\
-40\end{array}$ & $\begin{array}{l}303 \\
288 \\
273 \\
258 \\
243 \\
233\end{array}$ & $\begin{array}{r}1.1992 \\
1.0665 \\
.9320 \\
.7997 \\
.6711 \\
.5870\end{array}$ & $\begin{array}{r}.6853 \\
.6220 \\
.5580 \\
.4944 \\
.4306 \\
.3880\end{array}$ & $\begin{array}{l}1.75 \\
1.71 \\
1.67 \\
1.62 \\
1.56 \\
1.51\end{array}$ & $\begin{array}{l}17.4 \\
17.0 \\
16.5 \\
16.1 \\
15.6 \\
15.3\end{array}$ & $\begin{array}{l}101 \\
.101 \\
.101 \\
.101 \\
.100 \\
.099\end{array}$ \\
\hline $28.1 \ldots$ & $\begin{array}{r}30 \\
15 \\
0 \\
-15 \\
-30\end{array}$ & $\begin{array}{l}303 \\
288 \\
273 \\
258 \\
243\end{array}$ & $\begin{array}{r}1.1956 \\
1.0708 \\
.9404 \\
.8094 \\
.6792\end{array}$ & $\begin{array}{l}.7127 \\
.6424 \\
.5738 \\
.5066 \\
.4397\end{array}$ & $\begin{array}{l}1.68 \\
1.67 \\
1.64 \\
1.60 \\
1.55\end{array}$ & $\begin{array}{l}17.4 \\
17.0 \\
16.5 \\
16.1 \\
15.6\end{array}$ & $\begin{array}{l}.097 \\
.098 \\
.099 \\
.099 \\
.099\end{array}$ \\
\hline 21.4 & $\begin{array}{r}30 \\
15 \\
0 \\
-15\end{array}$ & $\begin{array}{l}303 \\
288 \\
273 \\
258\end{array}$ & $\begin{array}{r}1.1368 \\
1.0293 \\
.9155 \\
.7978\end{array}$ & $\begin{array}{l}.7442 \\
.6676 \\
.5944 \\
.5238\end{array}$ & $\begin{array}{l}1.53 \\
1.53 \\
1.54 \\
1.52\end{array}$ & $\begin{array}{l}17.4 \\
17.0 \\
16.5 \\
16.1\end{array}$ & $\begin{array}{l}.088 \\
.090 \\
.093 \\
.095\end{array}$ \\
\hline 14.7 & $\begin{array}{r}30 \\
15 \\
0\end{array}$ & $\begin{array}{l}303 \\
288 \\
273\end{array}$ & $\begin{array}{r}1.0122 \\
.9330 \\
.8441\end{array}$ & $\begin{array}{l}.7738 \\
.6916 \\
.6128\end{array}$ & $\begin{array}{l}1.31 \\
1.35 \\
1.38\end{array}$ & $\begin{array}{l}17.4 \\
17.0 \\
16.5\end{array}$ & $\begin{array}{l}.075 \\
.080 \\
.084\end{array}$ \\
\hline
\end{tabular}

TABLE 4.-Relation between resistivity, kinematic viscosity, and absolute temperature 


\section{COMPARISON WITH PREVIOUS DETERMINATIONS}

Comparatively few of our values can be compared directly with the values previously published. The International Critical Tables ${ }^{10}$ give values of conductivity for solutions at $18^{\circ} \mathrm{C}$ ranging in concentration from 4,000 to 11,000 milliequivalents per liter. These values are compared with ours in table 5 . In only one case is the difference as large as 0.5 percent, and the average difference is 0.24 percent.

\section{ACCURACY OF THE MEASUREMENTS}

Sources of error in determining the composition of the solution, the temperature and the resistance of the solution in the conductivity cell, all affect the accuracy of the measurements. Systematic errors in determining the composition of the solution have been avoided by checking the results of titrations by measurements of specific gravity. The greatest difference observed between these determinations could affect the values given by as much as 0.2 percent in the case of only 1 out of 9 solutions.

Accidental errors in measuring the temperature of the solution were probably the same as in the viscosity measurements. In the viscosity paper it was stated that above $-1^{\circ} \mathrm{C}$ the error in temperature measurement of a single determination did not exceed $0.05^{\circ} \mathrm{C}$. This would correspond to about 0.1 percent in the resistivity. Below $-1^{\circ} \mathrm{C}$ the errors of temperature measurement may have amounted to $0.2^{\circ} \mathrm{C}$. Between -25 and $-30^{\circ} \mathrm{C}$ this would correspond to 0.8 percent in the resistivity. The electrical measurements could be repeated to 0.1 percent.

TABLE 5.-Comparison of values of resistivity with data from International Critical Tables

(Ohm-centimeters at $\left.18^{\circ} \mathrm{C}\right)$

\begin{tabular}{|c|c|c|c|c|c|c|c|}
\hline Concentration & $\begin{array}{l}\text { I.C.T. } \\
\text { values } \\
\text { (recip- } \\
\text { rocals) }\end{array}$ & $\begin{array}{c}\text { Observed } \\
\text { values } \\
\text { (this } \\
\text { paper) }\end{array}$ & $\begin{array}{c}\text { Differ- } \\
\text { ence }\end{array}$ & Concentration & $\begin{array}{l}\text { I.C.T. } \\
\text { values } \\
\text { (recip- } \\
\text { rocals) }\end{array}$ & $\begin{array}{l}\text { Observed } \\
\text { values } \\
\text { (this } \\
\text { paper) }\end{array}$ & $\begin{array}{l}\text { Differ- } \\
\text { ence }\end{array}$ \\
\hline \multirow{2}{*}{$\begin{array}{c}\text { Millieq/liter } \\
4,000 \\
6,000 \\
6,000 \\
8,000\end{array}$} & \multirow{2}{*}{$\begin{array}{l}1.661 \\
1.486 \\
1.399 \\
1.361 \\
1.354\end{array}$} & \multirow{2}{*}{$\begin{array}{l}1.661 \\
1.492 \\
1.402 \\
1.361 \\
1.357\end{array}$} & \multirow{2}{*}{$\begin{array}{r}\text { Percent } \\
0.00 \\
.40 \\
.21 \\
.00 \\
.22\end{array}$} & \multirow{2}{*}{$\begin{array}{c}\text { Millieg/liter } \\
9,000 \\
11,0000 \\
\text { Average }\end{array}$} & $\begin{array}{l}1.375 \\
1.423 \\
1.500\end{array}$ & $\begin{array}{l}1.380 \\
1.430 \\
1.496\end{array}$ & $\begin{array}{r}\text { Percent } \\
0.36 \\
.49 \\
.27\end{array}$ \\
\hline & & & & & & & .24 \\
\hline
\end{tabular}

In view of the preceding statements and the comparison of our results with existing data at $18^{\circ} \mathrm{C}$, it seems probable that the results given in table 2 are not in error by more than 0.2 or 0.3 percent for measurements above $-1^{\circ} \mathrm{C}$ nor by more than 1 percent between -1 and $-20^{\circ} \mathrm{C}$. Below $-20^{\circ} \mathrm{C}$ the error may increase to 2 percent at the lowest temperatures.

Washington, July 18, 1934.

10 International Critical Tables 6, p. 241. 